\title{
educação

\section{A critical bicultural pedagogy of dance: Embodying cultural literacy}

\author{
Antonia Darder ${ }^{1}$ \\ Loyola Marymount University, United States of America \\ Sharon CRONIN ${ }^{I I}$ \\ Goddard College, United States of America
}

\begin{abstract}
The article examines the manner in which the use of a critical bicultural pedagogy of dance within oppressed communities in the United States can support the cultural literacy development of children, their families, and communities. At the heart of this particular examination is the AfroPuerto Rican practice of Bomba by Grupo Bayano in a Seattle community, where dance praxis serves as a pedagogical means for learning to read the world. As such, a critical bicultural pedagogy of dance functions to support the biculturation process of young children through the use of the body in culturally distinct and transformative ways.
\end{abstract}

Key-words: Critical pedagogy; Cultural literacy; The body; Biculturalism; Dance education

\section{INTRODUCTION}

The earliest language was the body and, since this language is the language of questions, if we limit the questions, and if we only pay attention to or place values on spoken or written language, then we are ruling out a large area of human language.

\section{Antonio Faundez in conversation with Paulo Freire (1989, pp. 37-38)}

We live in society where social and material oppression persists; where the cultural and linguistic subordination and repression of subordinate or subaltern cultures remains commonplace, despite overtures to the contrary. It persists in the lives of racialized communities, in the lives of poor workingclass people, in the lives of women, and in the lives of those whose sexuality is expressed outside the heteronormative. Yet, human beings do not grow suddenly into oppressed cultural subjects, but rather are systematically initiated into a political economy of economic enslavement and cultural subordination from the moment they are born. This is consistent with lived histories of cultural disaffiliation reinforced in schools and the historical legacies of traumatic dehumanization that continue to impact both individual and collective existence of subaltern populations in the United States. 
This process of Americanization, although often denied in the current educational context of neoliberal multiculturalism - where cultural representations abound without social and material shifts in power or wealth - is generally further, intensified, and solidified when poor working class children of color enter schools and are confronted with cultural deficit views that all they bring to the classroom is somehow mistaken or useless to their education and unspoken expectations that they assimilate themselves to the colonizing and patriarchal expectations of the dominant culture and class. This phenomenon in turn results in the oppressor/oppressed contradiction that Paulo Freire (1970) often signalled in his work, where the oppressed, rather than to transform the conditions of their oppression, take on the values, sensibilities, and expectation of those they perceive in power over their lives. This, in fact, can be understood as one of the strategies of survival often employed by bicultural human beings who are ushered into accommodating to the possibilities of assimilation and its rewards (Darder, 2012), at the expense of the cultural knowledge and wisdom that is their birthright.

We begin here, in that this essay seeks to briefly consider the ways in which cultural dances, which have persisted within the enslaved and colonizing contexts, have often functioned as means for emotional, psychological, physical, and spiritual survival, as well as for individual and communal empowerment, even when subaltern dance practices have been negated, rejected, exoticized, or commodified within the dominant society. We seek then to consider the ways in which the incorporation of a critical dance pedagogy in the education of young bicultural and bilingual children can function as an important form of embodied cultural literacy and decolonizing epistemological foundation, which offers a genuine cultural space for reading the world (Freire \& Macedo,
1987) and, therefore, inherent expressions of both communal and individual sensibilities that provide young children of color a much needed space to experience lived moments where they enjoy the freedom to be.

Toward this end, we reflect on a critical bicultural pedagogy of dance as decolonizing praxis and on the pedagogical significance of Bomba with young children of color in a community of Seattle. For over 30 years, Grupo Bayano's pedagogical integration of cultural dance forms has served as an important conduit for the creation of culturally emancipatory pedagogical spaces for young children and their families - pedagogical spaces that support culturally democratic life. Grupo Bayano, as a vital pedagogical force in communities, cultivates and nourishes the richness of cultural and spiritual knowledge that emerges from the histories of subaltern communities. Through a critical praxis of the body that employs cultural dances as key expressions of cultural literacy and the integration of an affirming and liberating bicultural curriculum for young children, the group brings dance to classrooms in ways that support critical bicultural development and the well-being of community life. As such, the use of regional cultural dances, and in this instance, Bomba - a traditional dance of Puerto Rico with African roots - young children and their families are introduced to a decolonizing vehicle for cultural and linguistic democracy.

The decolonizing sensibilities of a critical bicultural pedagogy of dance also challenges the absence of the arts in schools, particularly within working class communities of color, where art programs are generally the first to be eliminated whenever the exigencies of district budgets call for cutbacks. In the process, the absence of opportunities for evolving art expression among subaltern communities not only further relegates the arts to the confined 
cultural realm of the elite, but also repudiates and excludes those cultural expressions especially of the body - that fiercely counter the hegemonic constraints of mainstream values.

In addition, this absence of culturally responsive art programs and the lack of embodied sensibility for the societal impact of cultural subordination has often led to a deep cultural dissonance between the school and home cultures of young children (Cronin, 2003). Similarly, the absence of culturally democratic approaches to the arts in schools has resulted in the lack of interaction and meaningful understanding between the dominant society and subaltern communities, despite multicultural efforts of the past. This assimilative historical phenomenon within the U.S. educational system has consistently functioned to preserve an embedded colonizing tradition of education and the arts - founded on a Western epistemology that has deemed the colored bodies of the oppressed defective and disposable (Darder, 2011), as justification for their political, economic and social immobilization within an ostensibly free nation.

Yet, there is no question that multicultural books, activities and songs may, indeed, be found within the early childhood classroom curriculum. Nevertheless, many of these have become frozen and stagnant artefacts of practice that have unfortunately become cultural clichés to be included or checked off to show multicultural compliance, rather than ongoing living examples of bicultural existence. Nowhere is this more evident than in the arena of dance in early childhood education, where Eurocentric dance forms prevail, with the exception of occasional dances associated with cultural celebrations such as Cinco de Mayo. Also missing, then, is an integrated, consistent, and everyday use of dance in the education of working class children of color.

Similarly, when teachers do incorporate dance it is performed to taped music, rather than venturing out into communities and getting to know the musicians and dancers of cultural communities in which their students reside and integrating them as cultural teachers into the classroom. In the narrow perception of the arts often held by early childhood teachers, seldom are the arts understood as a living and breathing cultural phenomenon, in which children are politically and pedagogically affirmed and pride and confidence in their cultural communities unfolds. And although, recorded music and packaged dance curricula, as reified cultural artefacts, may provide an efficient and convenient educational product for consumption, these generally become stagnant and inadvertently reinforce passivity, further separating the culture of the school from the lived experience and cultural vitality that emerges from communal participation of cultural practices. This reflects a key point, in that most cultural communities in this country once experienced a multiplicity of cultural forms, depending on regional, class, racial, and historical traditions. Yet, these forms often remain invisible to most teachers and, consequently, soon even become inaccessible to bicultural community members, given the assimilative tradition of U.S. schooling and society.

\section{CRITICAL BICULTURALISM}

A critical bicultural understanding of human development is important to grasping key issues that are raised in this discussion of critical bicultural dance pedagogy. Critical biculturalism is articulated through a lens that openly acknowledges the dynamics of culture and power and asymmetrical power 
relations that result in cultural subordination. With this in mind, critical biculturalism refers to a phenomenon whereby members from subordinate cultural communities must learn to survive and function in the midst of inequalities structured by the dominant culture (Darder, 2012). This view acknowledges that subaltern human beings must consistently respond to daily struggles with racism and other forms of cultural invasion, including within educational settings. The tensions associated with bicultural development are thought to initiate whenever the dominant society exerts increasing influence or pressure on members of subordinate cultural communities, expecting their assimilation to the dominant institutional values, language, epistemology, and practices. It is often within this dynamic of cultural misalignment that resistance is said to develop, causing an intensified sense of cultural conflict.

The process of biculturation is then associated with efforts among the oppressed to reestablish the intrapsychic harmony of the primary culture, which is threatened by the relational tensions that arise from the dominant pressure exerted by the hegemonic culture to renounce the primary worldview rooted in the culture of origin. This process of bicultural developmental requires that individuals become increasingly able to recognize the value of the primary cultural community, while enacting adaptive behaviors and strategies that allow them to engage the dominant/subordinate dialectical tensions (Darder, 2012) or the oppressor/oppressed contradiction (Darder, 2015; Freire, 1970), in ways that support the integrity of their cultural and linguistic rights to be.

This view of bicultural development cannot be reduced to an absolute fixed moment or linear process. Instead, the critical quality of this decolonizing lens is retained precisely through a conceptualization of biculturalism as a complex and dynamic process that emerges through social participation in cultural practices, specifically tied to the survival of subaltern populations. Critical bicultural classroom practices - and critical bicultural dance pedagogy here - consciously seek to respond to the debilitating dynamics of cultural subordination and its impact on the lives of young children and their families, by engaging and supporting their bicultural formation as empowered historical subjects of their world.

The development of voice and expression of cultural literacy play a key role to this bicultural conceptualization in creating the conditions for cultural democracy in the classroom and the evolution of emancipatory social agency among children from subaltern populations. This refers to the manner in which bicultural voice and literacy practices are articulated and enacted within particular cultural communities, in ways that acknowledge the complexity of both human existence and the structures of inequality that inform the social and material conditions of their survival. With this in mind, critical bicultural pedagogical practices support "the unique instances of self-expression through which students affirm their own class, culture, racial, and gender identities... shaped by personal history and distinctive lived engagement with the surrounding culture" (Giroux, 1988, p. 199).

Similarly, critical bicultural dance pedagogy brings together available cultural dance forms, in order to create a space where children and their communities can make themselves understood and listened to, and with which to define themselves as empowered cultural beings. This concept of bicultural dance praxis provides an important basis for constructing and enacting the fundamental imperatives of cultural democracy within the educational 
experiences of young children of color. In concert, this decolonizing dance praxis can be said to emerge and evolve within an environment or relationships where children's cultural practices are fully validated, trusted, and welcomed. Four key features define this approach: 1) it is anchored in students histories, cultural knowledge, lived experiences, and an understanding of their everyday world; 2) it breaks the silences that young children of color often experience in the classroom, by expanding the field of communication in ways that legitimate their worldviews; 3 ) it links the sociopolitical development of critical consciousness and social agency in ways that support young children to build cultural knowledge anchored to community life; and 4) it nurtures an emancipatory expression of identity, community, and self-determination that reinforces children's evolving strengths and community possibilities for knowing and changing their world.

The purpose here, of course, is to support the evolution and establishment of a critical bicultural dance pedagogy that encompasses a deep sensibility to the issues, concerns, and cultural practices that support the intellectual, emotional, physical, and spiritual formation of young bicultural children and their communities. Accordingly, a critical bicultural practice of school and community practice is intimately linked to a humanizing ethos of life and an understanding that social justice practice requires a consciousness of political commitment and cultural integrity. This entails a critical consciousness that is founded upon the Freirean ideal that our vocation is to be human, and on a way of teaching and learning dance that is anchored in faith, love, hope and a vision where all cultural citizens of the world can bring the best they have to offer, for the evolution of our humanity and respect for the dignity of cultural multiplicity
- a vision that must be embodied early in the lives of all children.

\section{THE BODY AS CULTURAL EXPRES S I O N}

The body is truly the means through which we build relationship and communal life. Yet, as in all other aspects of human existence, the body is also governed by the cultural expressions of communities; and nowhere is this truer than in the midst of critical dance praxis. A critical perception of embodiment is then paramount to discussion of decolonizing dance pedagogy, in that to perceive young children in terms of only their individual minds or to employ only one way of cultural knowing in the midst of differences results in an objectifying and debilitating experience for them, despite the intellectual and cultural strengths they might possess. That said, young children must be engaged as embodied cultural beings and should be respected and treated as such (Cronin, 2003). The degree to which this is possible, however, is directly linked to how willing and able teachers are to be fully present, as well as their capacity to enter into intimate and meaningful relationships with young children, their parents, and their communities.

For this reason, enacting a critical pedagogy of the body within the context of dance demands that educators be cognizant of the social, political, and economic conditions that shape the cultural lives of young children and their communities. To do so entails the integration of critical principles that can support teachers of young children in use the medium of dance to consider ways in which they can work to transform classroom conditions of inequalities that reproduce the marginalization of colored bodies. In 
brief, this calls for an educational approach that encompasses the following principles of practice (Darder, 2011), associated with the incorporation of young children's body into the process of teaching and learning:

- Teachers engage the emotional and physical responses and experiences of young children as meaningful cultural indicators of strengths and limitations that they face in the process of their knowledge formation;

- Knowledge is understood as a historical and collective process, emanating from the body's relationship to the world. The body is seen as primary in efforts by young children to construct cultural knowledge and in the development of social and moral thought;

- The mind and its cognitive capacities are understood as only one medium for knowing the world. With this in mind, young children are seen as integral human beings, whose minds, bodies, hearts and spirits are all implicated in the cultural process of teaching and learning. This also speaks to the manner in which educational practices - and, in this instance, dance pedagogical practices - must reach young children within in ways that nurture their innermost emotional and psychic centers;

- Cultural knowledge derived from the body's collective interactions with others and the world constitutes a significant resource of human survival. Classroom and community relationships, materials, and activities must reflect this knowledge with both respect for cultural difference and the empowerment of subaltern bodies;

- Teaching and learning is understood as a cultural process of human labor that is intricately tied to the material conditions and social relations of power that shape classroom and community life.
Hence, the question of power and the uses of authority must be interrogated consistently in working with young children; knowledge construction is a collective, historical phenomenon that occurs continuously, both in and outside of the school environment. To privilege school knowledge and ignore the cultural lived experience of young children limits their capacities to participate effectively in the construction of knowledge;

- Educators are committed to creating meaningful interactions and activities within classrooms that support young children to grapple honestly with tensions of inequality they encounter daily, whether these are associated with race, class, gender, sexuality, or other forms of difference;

- The teachers' knowledge of their own bodies, including their sexuality, is an important teaching competency tied to cultural values and beliefs and is, thus, understood as significant to their ability to interact effectively with young bicultural children;

- Acts of resistance by young children tied to their bodies can signal meaningful and alternative ways of knowing and relating to the world. Opportunities are created for young children to reflect, affirm and challenge the meaning of these acts of resistance and their relationship to cultural subordination or liberation; Space is consistently created within classrooms to permit young children to experience the cultural aesthetics and material expressions of the body, including the expression of knowledge, music, dress, and cultural forms of participation; Decolonizing the body from educational and social constraints that limit and repress the development of social agency 
is a major intent within critical dance pedagogy of the body. Teachers work together with young children to challenge conditions within schools that can render them passive and domesticate their cultural expressions.

Critical bicultural dance pedagogy can assist both teachers and young children to recognize their bodies as integral transformative sites of liberation, within and outside the classroom environment. Utilizing community dance forms and musical rhythms supports practices that engage different cultural ways in which human bodies experience the world and perceive their place and social location with respect to others. Cultural dance forms within subaltern communities serve as powerful decolonizing practices of the body that create counterhegemonic spaces for young children to explore their place in the world.

Drawing on L. B. Blume's (2010) notions on embodied dance, the phenomenon of gender identities, for example, can be understood with respect to counterhegemonic possibilities:

Gender identities, defined as the existential sense of one's femaleness or maleness, differ in the degree to which concepts of gender are actively invoked in a particular situation (Schwartz \& Rutter, 2000). Individuals display particular sets of gender-relevant characteristics to define and verify their personal sense of masculinity and femininity (Spence \& Helmreich, 1980). Males and females tend to use gender-congruent characteristics to verify and maintain their gender identities and to discount their gender incongruent characteristics. Each person develops a set of beliefs and opinions about men and women and about the consensual categories of masculinity and femininity. (p. 96)

Within cultural dances of Latin America, for example, there are often found characteristics that reinforce traditional gender identities as expressed within each cultural or national milieu. However, because communal dances were never meant to exist as a stagnant phenomenon, contemporary expressions of cross-gender possibilities may be found within the work of more contemporary dance communities. So, for example, although generally it is the males that play the drum and females that wear the skirt, in Bomba, in the few instances where such cultural gender norms are loosened, females may be found playing the drum and males donning the skirt (although the latter less often), in that these forms of expression are considered organically in sync with the free expressive nature of the body. However, as in other gendered-specific activities in all societies, it must be noted that this is not considered the norm and is usually the result of early childhood teachers who are comfortable with their own bodies and who recognize that young children often explore other ways of being, including cross-gendered activities, in the process of their development.

In many respects, this view reflects a critical feminist perspective on gender, which argues that all reality grows out of a dialectical relationship between the self and the environment (Nakano Glenn, 2004). Drawing on Sherry Shapiro's $(1998,1999)$ writings on critical dance pedagogy, Blume (2010) notes: "In the critical dance classroom, students are encouraged to position themselves as embodied subjects in the cultural construction of gender" (p. 99). Bodies, then, are expressions of the wider culture; and, as such, critical bicultural dance pedagogy serves as a place for the exploration and expression of gender by young children, in ways that can potentially move them beyond hegemonic gendered formations. In so doing, this emancipatory pedagogy of dance creates a place for greater 
freedom of expression, through and within the practice of everyday cultural dance activities.

Within this cultural field of creative bodily expression, young bicultural children and their communities can critically experience a cultural literacy of the body. In this bicultural space of the body, emotional, psychological, and spiritual forms of human communication enacted through collective dance movements, young children discover a place where they can truly begin to know themselves as historical and transformative subjects of their individual and communal lives. It is precisely this sociopolitical concern for the empowerment of young bicultural children that distinguishes critical bicultural dance praxis from mainstream uses of dance within schools - which are generally limited to special performances and lack the deliberate intent that dance serve as a practice of freedom in the lives of children from oppressed communities. This is an important distinction in that, unfortunately, it is young children of color who tend to be most surveilled and controlled within everyday educational environments.

The significance of the body as terrain of emancipatory struggle, then, is also essential to comprehending the impact of oppressive domestication, which begins early in the lives of children from oppressed communities. Freire spoke to the manner in which domestication of the oppressed functions to not only limit educational opportunities and life choices, but to constrain emancipatory dreams (Darder, 2015; Freire, 1983). Moreover, we cannot forget that is the body that retains historical memories of individual and collective oppression. The historical memories of oppression are held in different parts of the body (i.e. back, shoulder, head, etc.) and the release of these stored tensions signal a process of emancipation that offers possibilities for transformation. This also can help us understand why communal dances can function as invigorating cultural spaces that counter the disabling impact of physical, emotional, psychological, and spiritual domestication, in ways that allow the body to release trauma through a communal decolonizing process of movement, fostering new ways to experience the world.

3. COMMUNAL DANCE AS DECOLONIZING PRAXIS

Communal dance in the practice of freedom can be associated with the flow of communal love and political grace (Darder \& Yiamouyiannis, 2009), which emerges from the cultural expression and collective interaction of drummers, dancers, singers, and observers in a dance form like Bomba. Through this practice, communal sensibilities dissuade individual competitive expression with the power of life affirming human engagement that unfolds within a decolonizing praxis of community. The dance becomes a shared space of cultural release and expression of one's individual and collective being, connected to all those who have danced before us and all those who will dance in the future. Knowledge that is embodied by and within decolonizing dance praxis can also be understood as a historical phenomenon that evolves and promotes the evolution of emancipatory consciousness essential to the collective empowerment of subordinated cultural communities.

In her discussion of a decolonizing praxis of dance, Ojeya Cruz Banks (2007) argues: "Critical dance education is pedagogy of the oppressed in the way it uses the body as dialogue for critical reflection, transformation, and public action imperative to social justice" (p. 133). Decolonizing dance pedagogy within bicultural communities can function as important forms, of both resistance against 
and healing from cultural oppression. Cruz Banks (2010) draws on the work of researchers in the field (Aschenbrenner, 2002; Browning, 1995; Daniels, 2005; Ousmare, 2005, 2007) to highlight "the way dance has become a way of acting in opposition to dominant culture" ( $p$. 21) and consider possibilities for countering legacies of racialized oppression. More importantly, since diasporic cultural dance forms represent creative spaces where often silenced voices and "identities are signaled" (Desmond, 1994, p. 34), it also serves as an important pedagogical space for children to begin developing social agency and bicultural consciousness with respect to self, community, and the world.

Inserting critical bicultural dance pedagogy into the early childhood education experience of working class children of color, as reflected in the work of Grupo Bayano, is essential to an evolving sense of cultural identity and selfdetermination as cultural beings. Through the use of Bomba, for example, children develop an organic and embodied comfort with their bodies, in ways that liberate them from the oppressive mainstream restrictions that generally function to restrict and contain the bodies of working class children of color. In contrast, when these children must negotiate alone the bicultural tensions they experience in response to assimilative classroom practices that restrict their bodies, they can become alienated from and, thus, initially resistant to participation in cultural dance activities. Cruz Banks (2010 explains this form of early resistance in students of color as "internalized racism", which can leave them culturally disassociated from their primary cultural heritage, given the absence of their histories and cultural traditions within mainstream educational environments.

In the experience of Grupo Bayano, such alienated forms of resistance generally dissipate as bicultural students become familiar with and open to the music, song, and dances. Through providing a cultural context where the movement of heads, feet, hips, arms, and hands are brought into the dialectical expression of individual/communal relationship, children begin to learn new values of not only moving but being in the world. Moreover, when introducing very young children of color to a decolonizing dance pedagogy early in their physical, cultural, and intellectual formation, within the context of community, their bicultural development and capacities for critical formation are supported and enhanced (Cronin, 2003; Darder, 2012), through the healing and release of internalized deficit notions so common to the experience of oppressed people who share a historical legacy of enslavement and colonization in the United States. Hence, the phenomenon of cultural healing, or la cultura cura, within the decolonizing dance context, is most apparent when "power, authority, [and the] community relationship are affected, rearranged and affirmed" (Daniels, 2005, p. 55).

What cannot be lost here is the manner in which a critical bicultural pedagogy of dance uses Bomba, in this instance, as a pedagogical force for cultural literacy - a bicultural reading of the world (Darder, 1991, 2012) - in this Seattle community. Within this decolonizing kinesthetic process, internalized asymmetrical relations of power are organically confronted by the shared integral relationship of music, song, and dance in community. In this way, Bomba functions as a decolonizing cultural form, when exercised in ways that confront and challenge the corporal epistemicides (Paraskeva, 2011) of the dominant classroom curriculum and shatter momentarily the epistemological abyssal divide (Santos, 2007) that constantly negate and repress the cultural differences of bicultural children and their communities, 
rendering the cultural knowledge, wisdom, and practices of subaltern communities as invisible and irrelevant to legitimate ways of teaching and learning. Ontologically speaking, Bomba offers a decolonizing communal space for both affective and physical being, through humanizing interactions that support children and their families in embracing a consciousness of emancipation toward self and community. In this way, critical bicultural dance pedagogy nurtures "a broader context of song, language, proverbs, and a connection to the people, aiming to cultivate a holistic view of the cultural knowledge of the dance" (Cruz Banks, 2010, p. 25).

\section{GRUPO BAYANO'S CRITICAL BICULTURAL DANCE PRAXIS}

Over 30 years, Grupo Bayano evolved organically from the steady efforts of early childhood educators, artists, and cultural workers of color in a Seattle community, who sought to create a pedagogical and cultural space for children and their families to build solidarity and understanding across their differences. Toward this end, a critical bicultural pedagogy of dance emerged that sought to nurture the conditions for student empowerment and support forms of cultural literacy and biliteracy that move beyond Eurocentrism and tokenistic applications of multicultural education (Banks, 2007, 2010). In line with Cruz Banks' (2010) Freirean insights of dance as a pedagogy of the oppressed, Grupo Bayano engage dance as a significant "repository of knowledge, history, and philosophy" (p. 26). As such, attention is focused on the integration of music, songs, and dances of the Afro-Latino diaspora. One of the key dances employed in their work is Bomba, derived predominantly from African, roots, with Spanish and Indigenous cultural influences, as are found intermingled in the culture of Puerto Rico and other Caribbean nations. Through the style and sensibilities of Bomba, young children in Seattle were introduced to the culture and history of Bomba in ways that supported a decolonizing sensibility. By so doing, issues of racism and other forms of oppression were engaged through a decolonizing embodied experience that enhanced cultural solidarity across the communities where children resided.

What is also valued in Grupo Bayano are creative spaces and places in which children improvise and communicate through their bodies personal forms of expression that are also linked to traditional forms of community expression which allows them to continue their participation in the legacy of dance as an act of freedom and social empowerment. Cultural predispositions are activated by the child's experience of the adults. Knowledge is scaffolded in the teaching of dance. In dance pedagogy, there is much modelling so children are hearing and being in the community, by codancing with children the steps, or language of the dance.

\subsection{DANCE AS A FORM OF CULTURAL PLAY}

Dance as a form of cultural play provides a spontaneous, joyful, loving, and playful field of movement, which opens bicultural children to the experience of communal participation as an embodied practice. Through their participation, they learn to emanate the warmth and interconnection of communal expression, as collective participation to the vibrations of the song, drums, and dance steps come together to generate a sense of emotional and spiritual solidarity. Bomba music and dance lends itself to this process because of its improvisational nature in that 
it was developed in the context of slavery and colonization as an expression of an itinerant and fluid epistemological way of knowing, in order to express, interpret, and read the world, for the purpose of liberating communities and reinventing that world. In contrast, dance instruction within the hegemonic culture of schooling derives from a different sensibility that is not generally tied to a decolonizing intent or a purpose of communal freedom.

\subsection{THE CLASSROOM SPACE}

There is a need to dedicate or create classroom space, indoor and outdoor, for children to dance together freely. A space that is culturally inviting, that encourages dance and where the drums have a home within the classroom become a part of the everyday life of the children. Cultural images or murals outside of people dancing together, a sound system for music to be played live, clothes and fabric in dramatic play area where children can do dance clothes or use instruments for community dance expressions. These spaces provide young children places to use their bodily expressions as forms of communication. Teachers also need to work out relationship between people who share space in a building with respect to the sound of the music, given that the drums and other instruments are integral to this dance pedagogy and bring an embodied cultural feel to the environment. It is important to note that Grupo Bayano combine the arts, so children experience the movement of their bodies, the sudatory stimulation of the instruments, and visual representations of dress and arts to promote an integral and multidimensional feel in the decolonizing praxis of Bomba.

\subsection{INTRODUCTION OF THE CHILDREN}

Since this is a communal space, parents and younger children are welcomed into the space. Babies experience the music and rhythm since they are in the womb. Within the cultural community of Bomba, teachers place the babies' feet on the drum as an introduction and presentation to the spirit of drum, allowing very young children to begin experiencing the feel of the drum with their bodies. This is also a way in which they experience the entire cultural community through the dance, letting the children know that the community is there.

The community holds this space for introduction of the children as a reference point for their cultural evolution. This is also a proud moment for the parents, in that the baby interacts with the drummer and is officially brought into the communal dance as a member of the community. Within the circle of Bomba, drums (along with other small instruments) are also provided for young children to begin to experience and distinguish the major rhythms of the dance, but also they begin to learn how to care for the drum as living being of the community, not a just thing to be pounded.

\subsection{THE CULTURAL LITERACY OF THE DRUM}

The drum is considered a living extension of the person who makes it, as is the Bomba skirt, which is an extension of the person who sews it. This is so, in that the instruments are made from living plant beings. The drums are built from old wooden barrels and animal skins, which are recovered and renewed, turned into living and sustainable artisanal beings that continue to nurture the community. With the process of the communal dance, the drum is infused with life through the repeated sounding (playing) of the drum, which seasons its existence and endears its place in the community.

The cultural literacy that emerges from the drum demarcates an ontological and epistemological worldview, which is generally 
undermined, ignored or denied within the epistemology of Eurocentric life, where object relations reinforce control and the mastery of the world is centered. This referred to earlier contrasts with the relational epistemology of the South (Santos, 2007) that conceives of human labor and its production as a relationship where the production and its creator are one. Songs, as living historical texts, teach history, cultural values, worldview, and the cosmology of the community from which they originate. By learning the songs, the children: 1) learn and preserve their language; and 2) connect with the cultural expressive forms of their regional communities. Often, songs name places which situate their cultural origin and significance.

\subsection{BUILDING A CULTURAL NEST}

Grupo Bayano, with members form different parts of Latin America and the Caribbean, emerged from social dances within family and community. Over the years, dancers from different parts would join the group and teach the members more about the history and roots of their dances, and this led to the group toward working with live musicians to learn from them and to evolve in the practice of communal dances. Community elders were integrated to support the group's development. Since many of the participants work with young children, Grupo Bayano brings Bomba into community settings, usually on Saturdays for young children, parents and community elders to come and dance and participate. Time and space was made for the children and adults to develop relationships within the context of their participation in the dance community.

Preschools are fairly new phenomena in our communities. Similarly, then it is important to include the instruments and the music as points of cultural engagement and relationship for children, in that these counters the
Eurocentric and assimilative curriculum of the preschool environment. This is key in that many bicultural children and their communities have become alienated from their cultural history and practices. Similar to the Maori practice of Kohnaga Reo or language nests (Grenoble \& Whaley, 2005, p. 54), as conceptualized by Maori early childhood educators Jean Puketapu and Dame Iritana Tawhiwhirangi (Thomson, 2015), Grupo Bayano has worked with community elders, parents, and community members to build a cultural nest for children through dance, creating literacy opportunities for children to actually experience in embodied ways those cultural practices that, through reclaiming them, provide them a means for reading the world as empowered bicultural subjects of history.

\subsection{THе ВомВАZо}

Bombazo refers to the communal dance context of Bomba, "where the community gathers to celebrate life through its rhythms, song and dance" (Tucker, cit. in Maldonado, 2015). This is a multi-age community space where Grupo Bayano works with babies, preschool children, school age children, youth, as well as multi-age adult. In this communal space, children also find a space to participate in different cultural activities together. Multiple instruments are provided and boys and girls are encouraged to learn all the parts of the dance, fostering a more open gender expression among the children. Always there is a creative tension between the practice with the children and the community, given the U.S. context often has functioned to segregate and separate the community life of children from that of adults. With the Bomba community, the cultural literacy inherent in a communal process of inclusion supports the development 
of communal spaces where adults and children interact and relish the beauty and power of the Bombazo.

This expectation - of adults and children laboring in the dance together - signals another important epistemological shift and powerful bicultural moment, which reinserts and centers a cultural literacy of shared communal life. As would be expected, this supports an open and evolutionary curriculum, which support a pedagogical space where the actual needs of all participants, whatever their ages, are integrated into the communal practice of Bomba.

\subsection{CRITICAL PRAXIS OF TEACHERS}

Teachers need to consider their own dance communities and the embodiment of these practices within their own communities. They must engage their own sensibilities with respect to their personal relationship to dance and music, as well as their experience in dancing with musicians and live instruments, etc. Whatever the case, teachers begin with themselves, as they do with young children, wherever the process of the communal dance feels most culturally familiar, slowly learning from the instruments and about their care and meaning. There is a need to establish and develop relationships with community members and cultural artists over time to nourish trust and faith in one another, so that teachers learn from the artists and artists from teachers. Through this process, teachers can engage the traditional cultural dimensions of Bomba in respectful ways; in ways that are in sync with cultural communities.

Grupo Bayano also uses Bomba as an important entryway for helping young children link to the cultural dances of other cultural communities. One effective way that teachers can carry out this praxis is to encourage children to ask their parents and grandparents about the cultural dances from their countries of origin and invite them to teach these dances in the classroom. This practice is also similar to one used by Milteri Tucker, the artistic director of the Bombazo Dance Company, when working with K-12 students. In this way, young children can come together to share their dances as a collective expression of their humanity. But what this activity also does "is help them find their cultural identity and preserve the stories of their elders" (Maldonado, 2015).

5. SYNERGY, SOLIDARITY, AND THE POWER OF COMMUNITY

The power of Bomba, as a communal dance experience, comes directly from the fact that collaboration and cooperation are central to this cultural practice. A critical dialectical relationship informs then the on-going dialogue between the dancer and drummer, who, together, create the space for creative and spiritual expression. Unmarked step activity during the communal process helps to demonstrate the alignment of movement between dancer and drummer, which creates the space for empowerment and leads to liberating expression of self and community. This must be understood as historical and, thus, cumulative process, that exists as part of lived historical experience of the community itself.

There is a necessary synergy and solidarity in Bomba practices that evolve through participation in the dance, in that the shared human relationship is essential to the dance itself. This requires a communal awareness of the needs of all participants -dancers, drummers, singers, and those holding the space. When a community of dancers joins a learning community, they bring their collective 
strength and energies that create an axis point or a flow between the dancers and the participants. This is done in combination with dialogue and forms of cultural literacy that are both spoken and danced, depending on the needs of the community. This sensibility for the power of dance to heal and unite opens the space for different languages and ways of being that provide validating and affirmation for other bicultural individuals in the group who may come from different regional traditions of communal dance. This has been an important dimension in introducing Bomba to young children. Often, older students from Puerto Rico speak about the absence of their primary culture within their experiences in schools. Hence, it is not surprising for bicultural students to seldom see their culture reflected in their education in the U.S.

Over the last three decades, affirming the community power of different cultural traditions within the work of Grupo Bayano has strengthened the Seattle community. In addition, their decolonizing praxis opened new possibilities for the expression of communal dance practices of other bicultural communities - communal dance practices that until recently had remained hidden and unacknowledged. Most importantly, through their critical bicultural pedagogy with children and their families, a historical and embodied space of cultural affirmation and political empowerment persists today.

\section{REFERÊ NCIAS}

Aschenbrenner, J. (2002). Katherine Dunham: Dancing a life. Urban, IL: University of Illinois Press.

Blume, L. B. (2010). Embodied [by] dance: Adolescent de/constructions of body, sex, gender in physical education. Sex education: Sexuality, society and learning, 3(2), 95-103.

Browning, B. (1995). Samba: Resistance in motion. Bloomington: Indiana University Press.

Cronin, S. (2003). Soy bilingüe: Language, culture, and young Latino children. Seattle, WA: Institute for Cultural and Linguistic Democracy.

Cruz-Banks, O. (2007). Decolonizing the body: An international perspective of dance pedagogy from Uganda to the United States. University of Arizona. Available at: https://repository. arizona.edu/bitstream/handle/10150/193853/ azu etd 2430 sip 1 m.pdf? sequence $=1$

Cruz Banks, O. (2010). Critical postcolonial dance pedagogy: The relevance of West African dance education in the United States. Anthropology \& Education Quarterly, 41(1), 18-34.

Daniels, Y. (2005). Dancing wisdom: Embodied knowledge in Haitian vodou, Cuban yoruba, and Bahian candomble. Urbana: University of Illinois Press.

Darder, A. (1991). Culture \& power in the classroom. Westport, CT: Bergin \& Garvey.

Darder, A. (2011). A dissident voice: Essays on culture pedagogy \& power. New York: Peter Lang.

Darder, A. (2012). Culture \& power in the classroom. Boulder, CO: Paradigm.

Darder, A. (2015). Freire \& education. New York: Routledge.

Darder, A., \& Yiamouyiannis, Z. (2009). Cultivating political grace: Toward a decolonizing approach to community practice. In J. Lavia \& M. Moore (Eds.), Crosscultural perspectives on policy and practice: Decolonizing community contexts (pp. 10-27). London: Routledge. 
Desmond, J. (1994). Embodying difference: Issues in dance and cultural studies. Cultural Critique, 26, 33-63.

Freire, P. (1970). Pedagogy of the oppressed. New York: Seabury Press.

Freire, P. (1983). Education for critical consciousness. New York: Seabury Press.

Freire, P. \& Faundez, A. (1989). Learning to question: A pedagogy of Liberation. London, UK: Continuum.

Freire, P., \& Macedo, D. (1987). Literacy: Reading the word \& the world. South Hadley, MA: Bergin \& Garvey.

Giroux, H. (1988). Schooling and the struggle for public life. Minneapolis: University of Minnesota Press.

Grenoble, L. A., \& Whaley, L. J. (2005). Saving languages: An introduction to language revitalization. Cambridge, UK: Cambridge University Press.

Maldonado, G. J. (2015). "Let's make that drum talk!": Interview with Milteri Tucker, Artistic Director of the Bombazo Dance Company. La Respuesta. Available at: http:// larespuestamedia.com/drum-talk-withmilteri/

Nakano Glenn, E. (2004). Unequal freedom. Cambridge, MA: Harvard University Press.

Ousmare, H. (2005). Global hip hop and African diaspora. In black cultural traffic: Crossroads. In H. J. Elam \& K. A. Jackson (Eds.), Global performance and popular culture (pp. 266288). Ann Arbor: University of Michigan Press.

Ousmare, H. (2007). The Africanist aesthetic in global hip-hop: Power moves. New York: MacMillan.

Paraskeva, J. (2011). Conflicts in curriculum theory. New York: Palgrave MacMillan.

Santos, B. de Sousa (2007). Beyond abyssal thinking: From global lines to ecologies of knowledges. Review, XXX, 45-89.

Shapiro, S. B. (1998). Dance, power, and difference: Critical and feminist perspectives in dance education. Champaign, IL: Human Kinetics.
Shapiro, S. B. (1999). Pedagogy and the politics of the body: A critical praxis. New York: Garland. Thomson, R. (2015). Celebrating New Zealand's first kohanga reo - 150 years of news. The Dominion Post. Available at: http://www. stuff.co.nz/dominion-post/news/huttvalley/73945639/celebrating-new-zealandsfirst-kohanga-reo--150-years-of-news 
UMA PEDAgOGIA BICULTURAL CRÍtICA DA DANÇA: ENCARNANDO A LITERACIA CULTURAL

\section{RESUMO}

O artigo analisa o modo como o uso de uma pedagogia bicultural crítica da dança com as comunidades oprimidas dos Estados Unidos pode apoiar o desenvolvimento da literacia cultural das crianças, das suas famílias e das comunidades. No centro desta análise específica está a prática afro-porto-riquenha da Bomba pelo Grupo Bayano numa comunidade em Seattle, onde a dança serve como meio pedagógico para aprender a ler o mundo. Como tal, uma pedagogia bicultural crítica da dança funciona para apoiar o processo de bi-aculturação das crianças pequenas, através do uso do corpo de modos culturalmente diferenciados e transformadores.

Palavras-chave: Pedagogia crítica; Literacia crítica; O corpo; Biculturalismo; Pedagogia da dança
PEDAgOGía CRítica Y BICULTURAL DE LA DANZA: ENCARNANDO LA A LFABETIZACIÓN C ULT URAL

\section{RESUMEN}

El artículo analiza cómo el uso de una pedagogía bicultural crítica de la danza con las comunidades oprimidas de los Estados Unidos puede apoyar el desarrollo de la alfabetización cultural de los niños, de sus familias y de las comunidades. En el centro de este análisis específico está la práctica afro-puertorriqueña de la Bomba por el Grupo Bayano en una comunidad en Seattle, donde la danza sirve como medio pedagógico para aprender a leer el mundo. Como tal, una pedagogía bicultural crítica de la danza funciona para apoyar el proceso de bi-aculturación de los niños pequeños, a través del uso del cuerpo de modos culturalmente diferenciados $y$ transformadores.

Palabras-Clave: Pedagogía crítica; Literacía crítica; El cuerpo; Biculturalismo; Pedagogía de la danza 